\title{
BXI open Deafness in children: a national survey of aetiological investigations
}

\author{
Shankar Rangan, ${ }^{1}$ Bernie Borgstein, ${ }^{2}$ Janet Lowe ${ }^{3}$
}

To cite: Rangan $S$

Borgstein B, Lowe J.

Deafness in children: a national survey of aetiological investigations. BMJ Open 2012;2:e001174.

doi:10.1136/bmjopen-2012001174

\section{- Prepublication history and additional material for this paper are available online. To view these files please visit the journal online (http://dx. doi.org/10.1136/bmjopen- 2012-001174)}

Received 26 June 2012 Accepted 15 August 2012

This final article is available for use under the terms of the Creative Commons Attribution Non-Commercial 2.0 Licence; see http://bmjopen.bmj.com

\footnotetext{
${ }^{1}$ Department of Audiovestibular Medicine, Halliwell Health and Children's Centre, Aylesford Walk, Bolton, UK ${ }^{2}$ Paediatric Audiology, Imperial College Healthcare NHS Trust, London, UK ${ }^{3}$ Paediatric Audiology, Hounslow and Richmond Community Healthcare Trust, London, UK
}

Correspondence to Dr Shankar Rangan; shankarrangan@yahoo.co.uk

\begin{abstract}
Objective: The aim of this study was to obtain national data regarding adherence to national guidelines for aetiological investigations for hearing loss in children and highlight any variations in practice. Information was also collected on possible factors affecting lack of adherence.
\end{abstract}

Design: An online questionnaire based on the national guidelines for aetiological investigations for deafness was designed.

Setting: The questionnaire was distributed to the leads of all the Newborn Hearing Screening Programme (NHSP) sites across England through the Medical Research Council Hearing \& Communication Group.

Participants: The questionnaire was sent to 100 recipients; from this 52 responses were obtained.

Outcome measures: Variability in the investigations offered for hearing loss.

Results: There was a $52 \%$ response rate. Analysis of the responses showed that audiovestibular physicians and paediatricians in audiology were more likely than other specialists to request level 1 investigations (investigations that are recommended to be offered in all cases). Respondents from London and the North West were more likely to request level 1 investigations compared with those from other regions. In all, 14 of the 19 audiovestibular physicians and paediatricians in audiology requested level 1 investigations routinely, but only 11 of 33 from other specialties did likewise. Of the 20 respondents from London and the Northwest, 15 requested level 1 investigations routinely, whereas only 10 of the 32 respondents from the other regions did the same. The difference was statistically significant in both cases. The geographical variation was specially marked for family audiograms and MRI.

Conclusions: There is significant variation from the national guidelines in requesting aetiological investigations for permanent hearing impairment (PHI) in children, depending on the specialty of the clinician and the geographical region, these variations appear partly to be due to the availability of local resources but also due to lack of awareness of the importance of some investigations.

\section{INTRODUCTION}

The incidence of permanent hearing impairment (PHI) in children in UK is approximately 1 in 1000 births, but this incidence

\section{ARTICLE SUMMARY}

Article focus

- The primary aim of the survey was to find out how the practice of aetiological investigations for deafness in children varied from the set guidelines.

- The secondary aim was to evaluate how different clinical specialties and different areas of the country varied from one another and look at the possible reasons for this.

\section{Key messages}

- There are significant variations from the national guidelines for aetiological investigations for deafness, depending on the specialty of the clinician and the geographical region.

- Some of the important investigations, such as family audiograms, MRI and Connexin mutation testing are not always being requested routinely. This has significant implications.

- There is a need for greater understanding of the role of various investigations among clinicians and better availability of resources.

Strengths and limitations of this study

- To the best of our knowledge, since the introduction of the Newborn Hearing Screening Programme (NHSP), there has been no study which has looked at the variations from the guidelines for aetiological investigations of permanent childhood hearing impairment (PCHI). This is the first study covering the whole of England looking at these variations.

- We obtained responses from all regions of the country (England) and a wide range of clinical specialists. This ensured there was a fair crosssectional representation of the various geographical regions and clinical specialties involved in investigating PCHI.

- This survey was aimed at the NHSP leads, but there could be other clinicians involved in arranging aetiological investigations for deaf children, they may not have been covered by this survey. This is one of the limitations of the survey. However, majority of the permanent hearing impairment (PHI) in children is now being diagnosed by NHSP; therefore, this survey would have covered a significant proportion of the clinicians involved in investigating PCHI. 
- The main limitation of this study was that the Medical Research Council (MRG) Hearing \& Communication group, which sent out the questionnaires on behalf of the authors, could not divulge details about the number of recipients in each strategic health authorities (SHA) or provide us with a breakdown of the specialty of all the recipients as they felt this would be a breach of confidentiality. It was not possible for the authors to find out this information as only the MRC Hearing \& Communication group had the relevant database. The specialty of the responders was known as this was a mandatory question. Since the specialty of all the recipients was not known, it was difficult to know if any one specialty had a higher percentage of return rates than others, which might create a bias. However, since there was a fairly symmetrical mix of specialty among the responders, the chance of any bias towards any one particular specialty is unlikely. Similarly, the number of responses received from each SHA was known, but the exact number of recipients in each SHA was unknown. Therefore, it is not known if a higher percentage of recipients responded from any particular SHA. Again, as for the specialty of the recipients, since there was a good distribution of responses from the various SHAs, bias towards any particular SHA would not be likely.

nearly doubles by 9 years of age as more children with PHI are identified. ${ }^{1}$ Those identified later include falsenegative cases from the Newborn Hearing Screening Programme (NHSP), children with acquired hearing loss and those with progressive deafness. ${ }^{2}$

Reasons for investigating the aetiology of PHI in children include; providing parents with information, improving understanding of the progress and natural history of deafness, identification of other pathologies such as Pendred or Usher syndrome to enable timely and appropriate management strategies, genetic counselling and to help in understanding the epidemiology of hearing loss. ${ }^{3}$

National guidelines for the aetiological investigations of deafness in children have been issued by the NHSP. ${ }^{3}$ The Guidelines were first published in 2003, but have been revised over the years. Investigations are categorised as levels 1 (box 1) and 2 (box 2) depending on the evidence base. Level 1 investigations should be offered in all cases, level 2 in selected cases depending on the clinical picture.

There is little evidence on adherence to the guidelines across the country. Wilson et al studied the current practice of aetiological investigation of children with bilateral severe-to-profound sensorineural hearing loss (SNHL) in Wales by sending postal questionnaires to all ear, nose and
Box 1 Level 1 investigations (investigations to be offered in all cases)

Level 1 investigations

1. General history, family history of hearing loss

2. Clinical, developmental examination

3. Family audiograms - first-degree relatives

4. MRI of inner ears/Internal Auditory Meati (IAM)

5. Test for Connexin 26 and 30 mutations

6. Ophthalmology referral

7. Congenital cytomegalovirus (cCMV) testing

8. Screening for other congenital infections-rubella, toxoplasma, syphilis

9. Urine examination-dipstick for blood and protein

throat (ENT) consultants and community paediatricians in audiology working in Wales. They found that community paediatricians reported higher usage of visual and developmental assessment, but less of imaging and ECG, whereas ENT consultants were less likely than other specialists to request ECG and urine analysis. They also found that community paediatricians performed more Level 2 investigations, mainly haematology, biochemistry and serology. Their study recommended greater use of ECG, urine analysis and ophthalmology referral.

Yoong and Spencer ${ }^{5}$ audited local performance against national guidelines for aetiological investigation of permanent childhood hearing impairment in Bradford. They found that almost $42 \%$ of the children were not offered imaging and about $20 \%$ were not referred to ophthalmology. They concluded that factors responsible for non-adherence to guidelines were lack of funding and parental choice.

Parker et $a t^{6}$ in 1999 reported a survey of clinical geneticists, in which they noted a great variation both in the services provided and in the recurrence risks quoted in isolated cases of childhood deafness. They sent postal questionnaires to 79 consultant clinical geneticists based at 26 centres across the UK. Just over half the respondents would ask for parental audiograms and only

Box 2 Level 2 investigations (investigations to be offered in specific conditions)

Level 2 investigations

1. Imaging-CT scan of petrous temporal bones, renal ultrasound

2. $E C G$

3. Genetics - test for mitochondrial mutation m.1555 $A>G$, chromosomal abnormalities or microdeletions, Pendrin gene in cases of dilated vestibular aqueduct (DVA) and/or Mondini anomaly, referral to clinical geneticist

4. Blood tests-full blood count, haemoglobinopathy screening, urea and electrolytes, thyroid function tests

5. Other investigations in specific situations, for example, autoimmune disease screen, metabolic screen, vestibular investigations and clinical photography 
around $10 \%$ requested imaging. In their survey, the commonest specific investigations requested were ECG, ophthalmological review, thyroid function tests, virology for congenital infection and urine analysis. They acknowledged the need to improve existing clinical and social understanding of childhood hearing impairment.

There has been no study which has looked at the practice and adherence to aetiological investigation guidelines across the country by specialty and geography. This study is a survey of current practice highlighting variations from the guidelines and recording differences in practice across the country together with possible reasons.

\section{DESIGN AND SETTING}

An online questionnaire (appendix) based on the National best practice guidelines for aetiological investigations offered to parents of children with bilateral severe-to-profound sensorineural hearing loss was sent electronically to the clinical leads of all NHSP sites across England through the Medical Research Council (MRC) Hearing \& Communication Group in February 2009. There were 119 NHSP sites, but some sites shared clinical leads and the questionnaires were sent to 100 recipients. The clinical lead was requested to forward the questionnaire to the person responsible for conducting aetiological investigations if it was not him or her. It was made clear that although the MRC was distributing the questionnaires, it was doing so as it held the relevant database but it was not involved in the study. Email reminders were sent by the MRC Hearing \& Communication Group to improve participation.

The Great Ormond Street Hospital for Children NHS Trust/Institute of Child Health Research Ethics Committee considered the project to be service/therapy evaluation and therefore ethical and Research \& Development (R\&D) approval were not required. The project was registered with the Greater Manchester Primary Care Research Governance Partnership (GM PC ReGrouP) for 'Notification Only' purposes.

\section{RESULTS}

A total of 52 responses were obtained; 50 online and two postal responses, giving a response rate of $52 \%$. The postal responses were received from respondents having technical problems with the online questionnaire. Responses were received from all strategic health authorities (SHA) with London and the North West returning more responses than other regions (10 each).

The respondents were grouped into five different specialties on the basis of their response to the mandatory question regarding their specialty. There were 15 paediatricians, 11 paediatricians in audiology, 8 community paediatricians, 8 audiovestibular physicians and 10 ENT surgeons.

Of the nine items listed in the level 1 investigations category, all respondents except one ENT surgeon indicated they would routinely take a detailed paediatric and family history. This ENT surgeon commented that he/she would do a routine ENT examination, but the paediatrician in the joint clinic also routinely saw the child. Apart from one each of audiovestibular physician, community paediatrician, ENT surgeon and paediatrician, all others indicated they would do a clinical examination including developmental assessment routinely.

The level 1 investigations showing the most variations between specialties for being requested routinely were family audiograms, Connexin testing and MRI scan of inner ears, with MRI having the maximum variation across specialties. Table 1 summarises the frequency with which the level 1 investigations were requested routinely by different specialists.

Audiovestibular physicians and paediatricians in audiology routinely requested family audiograms and ophthalmology referral more often than others. ENT surgeons were the least likely to request the level 1 investigations routinely. This difference was most notable for requesting MRI scan (20\% ENT surgeons and 100\% audiovestibular physicians).

Overall, audiovestibular physicians and paediatricians in audiology were more likely to request level 1 investigations routinely as compared to other specialties. This

Table 1 Comparison of the reported use of level 1 investigations between specialties showing percentage of respondents routinely requesting the tests

\begin{tabular}{|c|c|c|c|c|c|c|c|}
\hline & $\begin{array}{l}\text { Family } \\
\text { audio (\%) }\end{array}$ & $\begin{array}{l}\text { Ophthalmology } \\
(\%)\end{array}$ & $\begin{array}{l}\text { Urine } \\
\text { dipstick (\%) }\end{array}$ & $\begin{array}{l}\text { Serology } \\
(\%)\end{array}$ & $\begin{array}{l}\text { Connexin } \\
(\%)\end{array}$ & $\begin{array}{l}\text { MRI } \\
(\%)\end{array}$ & $\begin{array}{l}\text { Cytomegalovirus } \\
(\%)\end{array}$ \\
\hline Paediatricians & 67 & 93 & 80 & 67 & 93 & 33 & 67 \\
\hline $\begin{array}{l}\text { Paediatricians in } \\
\text { audiology }\end{array}$ & 91 & 91 & 73 & 82 & 82 & 73 & 73 \\
\hline ENT surgeons & 50 & 90 & 60 & 60 & 50 & 20 & 50 \\
\hline $\begin{array}{l}\text { Audiovestibular } \\
\text { physicians }\end{array}$ & 100 & 100 & 100 & 88 & 100 & 100 & 75 \\
\hline $\begin{array}{l}\text { Community } \\
\text { paediatricians }\end{array}$ & 75 & 100 & 88 & 75 & 100 & 63 & 75 \\
\hline
\end{tabular}


Table 2 Comparison between geographical regions for level 1 investigations showing percentage of respondents routinely requesting the tests. Only those regions with 5 or more responses have been included

\begin{tabular}{lccccccc}
\hline & $\begin{array}{l}\text { Family audio } \\
\text { (\%) }\end{array}$ & $\begin{array}{l}\text { Ophthalmology } \\
(\%)\end{array}$ & $\begin{array}{l}\text { Urine dipstick Serology } \\
(\%)\end{array}$ & $\begin{array}{l}\text { Connexin } \\
(\%)\end{array}$ & $\begin{array}{l}\text { MRI } \\
(\%)\end{array}$ & $\begin{array}{l}\text { Cytomegalovirus } \\
(\%)\end{array}$ \\
\hline London & 100 & 90 & 90 & 80 & 90 & 90 & 80 \\
North West & 100 & 100 & 90 & 80 & 90 & 80 & 60 \\
South West & 67 & 100 & 50 & 67 & 67 & 0 & 50 \\
East of England & 57 & 100 & 71 & 100 & 71 & 43 & 86 \\
West Mid & 60 & 80 & 100 & 80 & 80 & 40 & 40 \\
Yorkshire and & 0 & 80 & 60 & 80 & 80 & 0 & 80 \\
Humber & & & & & & & \\
\hline
\end{tabular}

difference was statistically significant (Fisher-FreemanHalton exact test, $\mathrm{p}=0.008$ ). The analysis was done by assigning the respondents to two groups, those requesting eight or more level 1 investigations routinely (first group), and those requesting seven or less routinely (second group). Of the total of 19 audiovestibular physicians and paediatricians in audiology, 14 were in the first group and 5 in the second. Of the 33 respondents from other specialties, only 11 were in first group, but 22 were in the second group. A contingency table analysis with $\chi^{2}$ and Fisher-Freeman-Halton exact test showed this difference to be statistically significant, with a $p$ value of $0.005 \quad\left(\chi^{2}=7.864535\right)$ and 0.0089 , respectively. The Fisher-Freeman-Halton exact test is more accurate as the numbers in the groups are relatively small.

Geographically, of the 20 respondents from North West and London, 10 made routine requests for level 1 investigations, whereas only 10 of the 32 respondents from the other regions did likewise. Analysis similar to that done for the specialties, showed this difference to also be statistically significant $\left(\chi^{2} \quad\left(x^{2}\right)=9.437037\right.$, $\mathrm{p}=0.002)$. All the respondents $(100 \%)$ from the North West and London reported requesting family audiograms routinely, compared to little more than one-half to two-third from other regions. The most striking difference was for the routine use of imaging, with none of the respondents from the South West requesting this routinely, compared to more than $80 \%$ from North West and London doing so (table 2).

\section{DISCUSSION}

Early identification of hearing loss and intervention results in a significantly better outcome for language development. ${ }^{7}$ With the implementation of the NHSP not only are more children with PHI being identified, ${ }^{8}$ the age at identification of the hearing loss has also reduced significantly. ${ }^{9}$ Looking for the cause of PHI in children can be a challenging but rewarding exercise, both for the parents and clinician. ${ }^{10}$ The yield from investigations is variable; the aetiology can remain unknown in about $40 \%$ cases, ${ }^{11}$ but as our knowledge increases this figure should decrease. ${ }^{10}$ A multidisciplinary and systematic approach increases the yield from investigations. ${ }^{12}$
The results from this study show a good awareness towards the importance of taking a detailed paediatric and family history and also carrying out a thorough examination, including developmental examination. There appeared to be major disparity between specialists in requesting family audiograms. One reason for this difference is a lack of resources in some parts of the country as indicated by comments from some of the respondents. One respondent stated that there was an ongoing negotiation and business case with the commissioners for family audiogram. Another respondent indicated that there were funding implications with family audiograms as only the patient would be paid for on payment by result (PBR). The other reason could be a lack of awareness of the importance of certain investigations such as family audiograms. Age-appropriate hearing assessment of first-degree relatives has been recommended even if there are no concerns, as unsuspected abnormalities may be uncovered and the configuration of the audiogram may also show a similar pattern among family members. ${ }^{2}$

The frequency of routinely testing for congenital cytomegalovirus (cCMV) appears to be less than optimal across all the specialist subgroups. CMV is the most common cause of congenital infections in humans ${ }^{13}$ and is a leading cause of non-hereditary SNHL. ${ }^{14-15}$ Children with both symptomatic and asymptomatic congenital CMV can develop SNHL. ${ }^{16}$ The hearing loss can be progressive or of delayed onset. ${ }^{16}$ Not diagnosing cCMV infection can have important implications as parents may not be counselled about the chance of concurrent disabilities. Another important reason for diagnosing cCMV is that early antiviral therapy has been shown to prevent onset or deterioration of hearing loss in both symptomatic $^{17}$ and asymptomatic ${ }^{18}$ cCMV infections. Therefore, routine testing for cCMV is important. The diagnosis of cCMV can also be made retrospectively from the child's dried blood spot (DBS or Guthrie card). This has been shown to be a valid and effective method, with the added advantage that diagnosis can be made after many years as the Guthrie card can be stored for long periods. ${ }^{19}$

The most common cause of genetic deafness is mutations in the Gap Junction Beta 2 gene (GJB2), located on chromosome $13 \mathrm{q}$ and encoding the protein 
Connexin $26 .^{20-21}$ The 35 delG mutation is the commonest $^{22-23}$ and has been reported to account for more than $80 \%$ of the GJB2 mutations in the Caucasian population. ${ }^{24}$ Homozygotes for the c.35delG mutation have been reported to have more significant hearing impairment than other genotypes. ${ }^{21} 25$ In this study, all audiovestibular physicians and community paediatricians and most of the paediatricians and paediatricians in audiology would offer Connexin testing routinely, but only half of ENT surgeons did so. Not diagnosing a case of genetic deafness such as GJB2 would mean that parents may not be counselled about the high risk of recurrence in future pregnancies.

The level 1 investigation which seemed to demonstrate the maximum variation according to specialty was MRI scan of Internal Auditory Meati (IAM). Whereas all audiovestibular physicians and three-quarters of paediatricians in audiology offered this routinely, only two-thirds of community paediatricians, a third of paediatricians and a fifth of ENT surgeons did so. This finding is quite different from that of Wilson et $a l^{4}{ }^{4}$ who found that community paediatricians requested imaging less often than ENT surgeons. Local policy and funding seems to be one of the factors influencing the decision of not offering routine imaging, especially from the community as three community paediatricians commented about the difficulty in arranging MRI scans. Decision of the individual clinician was another factor as five ENT surgeons commented that they would arrange for the MRI scan only if cochlear implantation was being considered. However, imaging has been shown to have a high diagnostic yield in the investigation of PHI in children ${ }^{26}$ and MRI is a level 1 investigation. High-resolution MRI has the added advantage of screening the central nervous system (CNS), enabling other neuro-developmental abnormalities to be detected. ${ }^{27}$ Characteristic findings on MRI can also lead to a retrospective diagnosis of congenital $\mathrm{CMV}^{28} \mathrm{~A}$ dilated vestibular aqueduct (DVA) is the commonest abnormality noted on imaging. ${ }^{2}$ The hearing loss in DVA can be progressive or there may be sudden drops in hearing triggered by minor head trauma. ${ }^{29}$ Identification of a DVA thus enables the clinician to give parents information on prognosis and to discuss important management strategies such as avoiding contact sports which have a risk of head trauma. DVA may also be associated with thyroid disease in Pendred syndrome and parents need to be counselled about this. Therefore, the use of MRI must not be limited to cases only where cochlear implantation is being considered, but should be offered to all children with permanent severe-to-profound hearing loss.

Most of the respondents routinely referred children with PHI for an ophthalmological assessment. This finding is in contrast to the finding of Wilson et at that a greater need for routine ophthalmological referral was needed. This may reflect a better understanding of the role and importance of various investigations, possibly contributed to by the NHSP 'aetiological investigations' courses over the years. The NHSP Quality Assurance
(QA) team visits to local NHSP sites would also have helped to improve the understanding of the role of the various aetiological investigations. Documents such as Quality standards in vision care for deaf children and young people (2009) published jointly by the the National Deaf Children's Society (NDCS) and Sense, add weight to the importance of checking the visual status of children with PHI. ${ }^{30}$

All audiovestibular physicians and most community paediatricians routinely requested urinalysis or urine dipsticks, but less than two-thirds of ENT surgeons did likewise. This finding was similar to that of Wilson et $a l^{4}$ However, the importance of routine urine analysis in the investigation of PHI in the neonatal period can be debated. The average age of presentation with deafness in Alport syndrome is reported to be 11 years, ${ }^{31}$ a routine urinalysis in the neonate would not necessarily identify this condition and it would need to be repeated in mid-childhood, especially if no cause for the hearing loss has been found or if the hearing loss is progressive.

A bogus question; positron emission tomography (PET) was added to the list of investigations in the questionnaire to increase the validity of the responses. A PET scan is not listed in the investigations recommended in the national guidelines and currently does not form a part of the investigation for PHI in children. Therefore, if any of the respondents had indicated they would offer this routinely, the validity of the rest of their responses could be questioned. However, none of the 52 respondents indicated they would offer a PET scan routinely.

For the question 'Would your answers have been the same for a child with Unilateral severe-to-profound deafness'; $59 \%$ answered 'no' and 41\% 'yes'. For the question 'Would your answers have been the same for a child with mild-to-moderate degree of hearing loss'; $62 \%$ answered 'no' and 38\% 'yes'. There are now guidelines for investigation of unilateral and mild-to-moderate sensorineural hearing $\operatorname{loss}^{32}$, but these guidelines are not evidence based.

One of the limitations of the study was the response rate of $52 \%$. However, this response rate could be considered quite acceptable as often the response rate to questionnaires without personal (face to face or telephone) contact with the respondent can be as low as $20 \%{ }^{33}$ One reason for non-response could be due to the method by which the questionnaires had to be distributed. The questionnaires were sent electronically to all the clinical NHSP leads. However, the clinical lead may not be the person carrying out the investigation in all areas. Even though the covering letter accompanying the questionnaire requested the clinical lead to forward the questionnaire to the appropriate individual, this may not have happened in all cases, thereby reducing the response. Another factor could be that those who responded to the survey are the ones more likely to be carrying out the investigations as per the national guidelines and those who do not comply with the guidelines not responding. Therefore, the real proportion of 
families offered the full battery of level 1 investigations may be even lower than shown in this survey.

The main limitation of this study was that the MRC Hearing \& Communication group, which sent out the questionnaires on behalf of the authors, could not divulge details about the number of recipients in each SHA or provide us with a breakdown of the specialty of all the recipients as they felt this would be a breach of confidentiality. It was not possible for the authors to find out this information as only the MRC Hearing \& Communication group had the relevant database. The specialty of the responders was known as this was a mandatory question. Since the specialty of all the recipients was not known, it was difficult to know if any one specialty had a higher percentage of return rates than others, which might create a bias. However, since there was a fairly symmetrical mix of specialty among the responders, the chance of any bias towards any one particular specialty is unlikely. Similarly, the number of responses received from each SHA was known, but the exact number of recipients in each SHA was unknown. Therefore, it is not known if a higher percentage of recipients responded from any particular SHA. Again, as for the specialty of the recipients, since there was a good distribution of responses from the various SHAs, bias towards any particular SHA would not be likely.

This survey highlights the variations from the national guidelines for aetiological investigations of children with PHI. While in some cases this variation has been due to lack of resources, in others this seems to be due to individual choice of the clinician. It seems unlikely that unavailability of MRI scanning or genetic testing would be the only reason these are not offered in all cases. Similarly, not routinely requesting cCMV testing could be due to a lack of appreciation of the importance and implications of this, as it would be unlikely that access to cCMV testing is not available to all clinicians. Clinicians not offering the investigations according to guidelines by choice should be encouraged to change their practice so that the investigations offered for childhood PHI is standardised across the country. We also hope the findings of inequality, due to resources, between geographical regions highlighted in this study would give the clinicians a tool to argue for more funding and resources. Although, over the years the understanding of the role and importance of various investigations for deafness has increased, there is a need for further improvement.

\section{CONCLUSIONS}

In this study, variations from the national guidelines have been noted, both according to the specialty of the clinician and geographical region. Although some of the variations appear partly to be due to availability of local resources, there also seems to be a lack of awareness of the importance of some investigations. This study emphasises the need for greater understanding and availability among clinicians of the role of various investigations for PHI in children. Routine use of Connexin testing, MRI, cCMV testing and family audiograms should be encouraged.

Acknowledgements The authors would like to acknowledge the following: Ms Denise Duhaney, Newborn Hearing Screening Programme (NHSP) co-ordinator at the Medical Research Council Hearing \& Communication Group for painstakingly collating the list of NHSP clinical leads and sending the questionnaire to them. Mr Andy Vail, medical statistician at Salford Royal NHS Foundation Trust for all the help and support provided with the statistical analysis. Mr Malcolm Wilson of the IT department at Bolton PCT for designing the online study questionnaire.

Contributors SR made substantial contributions to conception design, acquisition of data or analysis and interpretation of data and final approval of version to be published. BB was responsible for drafting the article or revising it critically for important intellectual content. JL was responsible for drafting the article or revising it critically for important intellectual content

\section{Competing interests None.}

Ethics approval The Great Ormond Street Hospital for Children NHS Trust/ Institute of Child Health Research Ethics Committee.

Provenance and peer review Not commissioned; externally peer reviewed.

Data sharing statement Dataset and details of statistical analysis will be available from the corresponding author at shankarrangan@yahoo.co.uk. The presented data are anonymised and risk of identification is low.

\section{REFERENCES}

1. Fortnum HM, Quentin Summerfield A, et al. Prevalence of permanent childhood impairment in the United Kingdom and implications for universal hearing screening: questionnaire based ascertainment study. BMJ 2001;323:536-9.

2. Mac Ardle B, Bitner-Glindzicz M. Investigation of the child with permanent hearing impairment. Arch Dis Child Educ Pract Ed 2010;95:14-23.

3. Guidelines for aetiological investigations of infants with congenital hearing loss identified through newborn hearing screening-Best practice guidelines, January 2009; http://www.hearing.screening.nhs. uk (accessed Feb 2009).

4. Wilson C, Roberts A, Stephens D. Aetiological investigation of sensorineural hearing loss in children. Arch Dis Child 2005;90:307-9.

5. Yoong S, Spencer N. Audit of local performance compared with standards recommended by the national guidelines for aetiologic investigation of permanent childhood hearing impairment. Child Care Health Dev 2005;31:649-57.

6. Parker MJ, Fortnum H, Young ID, et al. Variations in genetic assessment and recurrence risks quoted for childhood deafness: a survey of clinical geneticists. J Med Genet 1999;36:125-30.

7. Yoshinaga-Itano C, Coulter D, Thomson V. Developmental outcomes of children with hearing loss born in Colorado hospitals with and without Universal Newborn Hearing Screening programs. Semin Neonatol 2001;6:521-9.

8. Mehl AL, Thomson V. Newborn Hearing Screening: the great omission. Pediatrics 1998;101:E4.

9. Bamford J, Ankjell H, Crockett R, et al. Evaluation of the newborn hearing screening programme (NHSP) in England. Report of the evaluation of the first phase of implementation of the NHSP: volume one: studies, results and recommendations. Eval Funded Dept Health 2004;1-246.

10. Bamiou DE, Macardle B, Bitner-Glindzicz M, et al. Aetiological investigations of hearing loss in childhood: a review. Clin Otolaryngol 2000;25:98-106.

11. Morzaria S, Westerberg BD, Kozak FK. Systematic review of the etiology of bilateral sensorineural hearing loss in children. Int $J$ Paediatr Otorhinolaryngol 2004;68:1193-8.

12. Parving A. Epidemiology of hearing loss and aetiological diagnosis of hearing impairment in childhood. Int $J$ Paediatr Otorhinolaryngol 1983;5:151-65.

13. Peckham CS, Stark O, Dudgeon JA, et al. Congenital cytomegalovirus infection; a cause of sensorineural hearing loss. Arch Dis Child 1987;62:1233-7. 
14. Pass RF. Congenital cytomegalovirus infection and hearing loss. Herpes 2005;12:50-5.

15. Boppana SB, Pass RF, Britt WJ. Symptomatic congenital cytomegalovirus infection: neonatal morbidity and mortality. Pediatr Infect Dis J 1992;11:93-9.

16. Dahle AJ, Fowler KB, Wright JD, et al. Longitudinal investigation of hearing disorders in children with congenital cytomegalovirus. J Am Acad Audiol 2000;11:283-90.

17. Kimberlin DW, Lin CY, Sanchez PJ, et al. Effect of ganciclovir therapy on hearing in symptomatic congenital cytomegalovirus disease involving the central nervous system: a randomized, controlled trial. J Pediatr 2003;143:16-25.

18. Lackner A, Acham A, Alborno T, et al. Effect on hearing of ganciclovir therapy for asymptomatic congenital cytomegalovirus infection: four to 10 year follow up. J Laryngol Otol 2009;123:391-6.

19. Barbi M, Binda S, Caroppo S. Diagnosis of congenital CMV infection via dried blood spots. Rev Med Virol 2006;16:385-92.

20. Bajaj Y, Sirimanna T, Albert DM, et al. Spectrum of GJB2 mutations causing deafness in the British Bangladeshi population. Clin Otolaryngol 2008;33:313-18.

21. Cryns K, Orzan E, Murgia A, et al. A genotype-phenotype correlation for GJB2 (connexin 26) deafness. J Med Genet 2004:41:147-54.

22. Angeli S, Utrera R, Dib S, et al. GJB2 gene mutations in childhood deafness. Acta Otolaryngol 2000;120:133-6.

23. Picciotti PM, Pietrobono R, Neri G, et al. Correlation between GJB2 mutations and audiological deficits: personal experience. Eur Arch Otorhinolaryngol 2008:266:489-94.

24. Estivill X, Fortina P, Surrey S, et al. Connexin 26 mutations in sporadic and inherited sensorineural deafness. Lancet 1998:351:394-8.
25. Snoeckx RL, Huygen PL, Feldman D, et al. GJB2 mutations and degree of hearing loss: a multicenter study. Am J Hum Genet 2005;77:945-57.

26. Antonelli PJ, Varela AE, Mancuso AA. Diagnostic yield of high resolution computed tomography for paediatric sensorineural hearing loss. Int J Paediatr Otorhinolaryngol 1999;70863-8.

27. Lapointe A, Viamonte C, Morris MC, et al. Central nervous system findings by magnetic resonance in children with profound sensorineural hearing loss. Int $J$ Paediatr Otorhinolaryngol 2006;70:863-8.

28. Haginoya $\mathrm{K}$, Ohura $\mathrm{T}$, Kon $\mathrm{K}$, et al. Abnormal white matter lesions with sensorineural hearing loss caused by congenital cytomegalovirus infection: retrospective diagnosis by PCR using Guthrie cards. Brain Dev 2002:24:710-14.

29. Colvin IB, Beale T, Harrop-Griffiths K. Long term follow-up of hearing loss in children and young adults with enlarged vestibular aqueducts: relationship to radiologic findings and Pendred syndrome diagnosis. Laryngoscope 2006;116:2027-36.

30. Quality standards in vision care for deaf children and young people (2009) — published jointly by National Deaf Children's Society (NDCS) and Sense. Copies available from their websites-http:// www.ndcs.org.uk and http://www.sense.org.uk (accessed Jul 2012).

31. Flinter F. Alport's syndrome. J Med Genet 1997;34:326-30.

32. 'Aetiological Investigation into bilateral mild to moderate permanent hearing loss in children' and 'Medical evaluation of children with permanent unilateral hearing loss'. Produced by the British Association of Audiovestibular Physicians and British Association of Paediatricians in Audiology, August 2009. http://www.baap.org.uk (accessed Jan 2010).

33. Kelly K, Clark B, Brown V, et al. Good practice in the conduct and reporting of survey research. Int J Qual Health Care 2003;15:261-6.

\section{APPENDIX: QUESTIONNAIRE: AETIOLOGICAL INVESTIGATIONS FOR CHILDREN WITH PERMANENT HEARING IMPAIRMENT (PHI) \\ Which of the following would you offer to the parent of a child with bilateral severe-to-profound sensorineural deafness?}

\begin{tabular}{|c|c|c|c|c|c|}
\hline & Routinely & Sometimes & Rarely & $\begin{array}{l}\text { Not offered- } \\
\text { clinicians } \\
\text { choice }\end{array}$ & $\begin{array}{l}\text { Not offered- } \\
\text { other } \\
\text { reasons }\end{array}$ \\
\hline $\begin{array}{l}\text { Detailed paediatric history including family history of } \\
\text { deafness } \\
\text { Comments }\end{array}$ & $\square$ & $\square$ & $\square$ & $\square$ & $\square$ \\
\hline $\begin{array}{l}\text { Clinical examination including developmental assessment } \\
\text { Comments }\end{array}$ & $\square$ & $\square$ & $\square$ & $\square$ & $\square$ \\
\hline $\begin{array}{l}\text { Family audiograms for first-degree relatives } \\
\text { Comments }\end{array}$ & $\square$ & $\square$ & $\square$ & $\square$ & $\square$ \\
\hline $\begin{array}{l}\text { ECG } \\
\text { Comments }\end{array}$ & $\square$ & $\square$ & $\square$ & $\square$ & $\square$ \\
\hline $\begin{array}{l}\text { Ophthalmology referral } \\
\text { Comments }\end{array}$ & $\square$ & $\square$ & $\square$ & $\square$ & $\square$ \\
\hline $\begin{array}{l}\text { Urine for dipstix (haematuria, proteinuria) } \\
\text { Comments }\end{array}$ & $\square$ & $\square$ & $\square$ & $\square$ & $\square$ \\
\hline & Routinely & Sometimes & Rarely & $\begin{array}{l}\text { Not done } \\
\text { by choice }\end{array}$ & $\begin{array}{l}\text { Not done } \\
\text { due to other } \\
\text { reasons }\end{array}$ \\
\hline $\begin{array}{l}\text { Serology/TORCH (Toxoplasma, Others - Syphilis, Rubella, } \\
\text { Cytomegalovirus, Herpes Simplex) investigations } \\
\text { Comments }\end{array}$ & $\square$ & $\square$ & $\square$ & $\square$ & $\square$ \\
\hline $\begin{array}{l}\text { Haematology and biochemistry (full blood count, U \& E) } \\
\text { Comments }\end{array}$ & $\square$ & $\square$ & $\square$ & $\square$ & $\square$ \\
\hline $\begin{array}{l}\text { Thyroid function tests } \\
\text { Comments }\end{array}$ & $\square$ & $\square$ & $\square$ & $\square$ & $\square$ \\
\hline $\begin{array}{l}\text { Immunology tests (eg, autoimmune markers, inflammatory } \\
\text { markers) } \\
\text { Comments } \\
\text { Metabolic screen }\end{array}$ & $\square$ & $\square$ & $\square$ & $\square$ & $\square$ \\
\hline Blood & $\square$ & $\square$ & $\square$ & $\square$ & $\square$ \\
\hline
\end{tabular}




\begin{tabular}{|c|c|c|c|c|c|}
\hline & Routinely & Sometimes & Rarely & $\begin{array}{l}\text { Not offered- } \\
\text { clinicians } \\
\text { choice }\end{array}$ & $\begin{array}{l}\text { Not offered- } \\
\text { other } \\
\text { reasons }\end{array}$ \\
\hline $\begin{array}{l}\text { Urine } \\
\text { Comments }\end{array}$ & $\square$ & $\square$ & $\square$ & $\square$ & $\square$ \\
\hline $\begin{array}{l}\text { Blood for Connexin mutation testing } \\
\text { Comments }\end{array}$ & $\square$ & $\square$ & $\square$ & $\square$ & $\square$ \\
\hline $\begin{array}{l}\text { Blood for other mutations (eg, A1555G) } \\
\text { Comments } \\
\text { Tests for CMV }\end{array}$ & $\begin{array}{l}\text { Routinely } \\
\square\end{array}$ & $\begin{array}{l}\text { Sometimes } \\
\square\end{array}$ & $\begin{array}{l}\text { Rarely } \\
\square\end{array}$ & $\begin{array}{l}\text { Not done } \\
\text { by choice } \\
\square\end{array}$ & $\begin{array}{l}\text { Not done } \\
\text { due to other } \\
\text { reasons } \\
\square\end{array}$ \\
\hline $\begin{array}{l}\text { Urine } \\
\text { Blood } \\
\text { Guthrie card }\end{array}$ & $\begin{array}{l}\square \\
\square \\
\square\end{array}$ & $\begin{array}{l}\square \\
\square \\
\square\end{array}$ & $\begin{array}{l}\square \\
\square \\
\square\end{array}$ & $\begin{array}{l}\square \\
\square \\
\square\end{array}$ & $\begin{array}{l}\square \\
\square \\
\square\end{array}$ \\
\hline $\begin{array}{l}\text { Comments } \\
\text { MRI of Internal Auditory Meati } \\
\text { Comments }\end{array}$ & $\square$ & $\square$ & $\square$ & $\square$ & $\square$ \\
\hline $\begin{array}{l}\text { CT scan of petrous temporal bone } \\
\text { Comments }\end{array}$ & $\square$ & $\square$ & $\square$ & $\square$ & $\square$ \\
\hline $\begin{array}{l}\text { Renal ultrasound } \\
\text { Comments }\end{array}$ & $\square$ & $\square$ & $\square$ & $\square$ & $\square$ \\
\hline $\begin{array}{l}\text { Clinical photography } \\
\text { Comments }\end{array}$ & $\square$ & $\square$ & $\square$ & $\square$ & $\square$ \\
\hline $\begin{array}{l}\text { Chromosomal studies } \\
\text { Comments }\end{array}$ & $\square$ & $\square$ & $\square$ & $\square$ & $\square$ \\
\hline $\begin{array}{l}\text { PET scan } \\
\text { Comments }\end{array}$ & $\begin{array}{l}\text { Routinely } \\
\square\end{array}$ & $\begin{array}{l}\text { Sometimes } \\
\square\end{array}$ & $\begin{array}{l}\text { Rarely } \\
\square\end{array}$ & $\begin{array}{l}\text { Not done } \\
\text { by choice } \\
\square\end{array}$ & $\begin{array}{l}\text { Not done } \\
\text { due to other } \\
\text { reasons } \\
\square\end{array}$ \\
\hline $\begin{array}{l}\text { Referral to Clinical Geneticist } \\
\text { Comments }\end{array}$ & $\square$ & $\square$ & $\square$ & $\square$ & $\square$ \\
\hline $\begin{array}{l}\text { Vestibular investigations } \\
\text { Comments }\end{array}$ & $\square$ & $\square$ & $\square$ & $\square$ & $\square$ \\
\hline
\end{tabular}

Others: please list

Would your answers have been the same for a child with unilateral severe-to-profound deafness?

Yes $\square \quad$ No

Would your answers have been the same for a child with other degrees of hearing loss (mild or moderate)?

Yes $\square \quad$ No

Are there any investigations that you would like to do regularly, but cannot, due to non-availability of resources or other constraints. Please comment.

Any other comments 
Specialty of person filling the form (eg, audiovestibular physician, paediatrician, ear, nose and throat (ENT), etc) (mandatory question)

Email of the person filling the form

PCT or Strategic Health Authority covered (mandatory question) 